This document is the accepted manuscript version of the following article:

Muoth, C., Aengenheister, L., Kucki, M., Wick, P., \& Buerki-Thurnherr, T. (2016). Nanoparticle transport across the placental barrier: pushing the field forward!. Nanomedicine, 11(8), 941-957.

https: //doi .org/10.2217/nnm-2015-0012

\title{
Nanoparticle transport across the placental barrier: Pushing the field forward!
}

Carina Muoth, Leonie Aengenheister, Melanie Kucki, Peter Wick, Tina Buerki-Thurnherr

Empa - Swiss Federal Laboratories for Materials Science and Technology, St. Gallen, Switzerland

\begin{abstract}
The human placenta is a multifunctional organ constituting the barrier between maternal and fetal tissues. Nanoparticles can cross the placental barrier, and there is increasing evidence that the extent of transfer is dependent on particle characteristics and functionalization. While translocated particles may pose risks to the growing fetus particles may also be engineered to enable new particle-based therapies in pregnancy. In both cases, a comprehensive understanding of nanoparticle uptake, accumulation and translocation is indispensable and requires predictive placental transfer models. We examine and evaluate the current literature to draw first conclusions on the possibility to steer translocation of nanoparticles. In addition, we discuss if current placental models are suitable for nanoparticle transfer studies and suggest strategies to improve their predictability.
\end{abstract}

\section{Keywords}

placenta, nanoparticle translocation, advanced in vitro models

\section{Nanoparticle transport across the placental barrier - Why should we care?}

Selective transport of gases, essential nutrients, metabolic waste products and exclusion of harmful substances are among the key functions of the placental barrier. To fulfill the requirements of a highly effective barrier, a unique polarized epithelial cell layer, the so-called syncytiotrophoblast, is formed during the early days of pregnancy. It constitutes the primary barrier between maternal and fetal tissue and expresses a plethora of specific transporters, which function as either importers or exporters [1-3]. In addition, the chorionic connective tissue and the fetal endothelium supposedly also contribute towards placental barrier function. Nonetheless, the placental barrier does not provide perfect protection to the growing fetus although this was believed for a long time. Since the thalidomide scandal in the 1960's, if not earlier, the awareness of potential harm by drugs has raised and placental transfer has in the meantime been described for many environmental and pharmaceutical compounds $[3,4]$. Nanomaterials are no exception and recent research indicates that certain nanoparticles (NP) can reach the fetal circulation and accumulate in fetal organs [5-7]. For some NP types such as carbon nanotubes there is evidence of potential teratogenic effects but it is not yet clear if these are caused by translocated particles (direct effects) or due to a release of maternal or placental mediators (indirect effects) [7-9]. 
Maternal exposure to engineered nanomaterials is not just a fictive scenario anymore but becomes more common with the ever-increasing production and usage of these materials in various consumer products.

On the other hand, engineered nanomaterials are increasingly being used to develop novel medical therapies. Indeed, several examples show that NPs can successfully be applied as drug carriers, for molecular diagnostics or targeted therapy [10, 11]. NP-based medicine offers unique advantages, such as the targeting of specific cells or tissues. NP-based carriers with large surface to volume ratio can be decorated with different ligands and/or loaded with cargo in order to minimize dosing and side effects among others [12, 13]. In pregnancy, no nanomedical therapies have yet been established; however, the clinical need for improved drug delivery systems with high selectivity and safety is tremendous [13]. Prescription drug use in pregnancy is widespread in many developed countries despite the fact that comprehensive safety and efficacy data for most drugs are essentially missing [13-15]. Alarmingly, the use of medicines with positive evidence of risk (FDA category $D$ ) has been shown to range from $2 \%$ (Italy; 2004) to $59.3 \%$ (France; 1995-2001) [15]. With regard to unwanted side effects, NPbased drug carriers hold great promise to steer placental translocation, thereby enabling new ways to specifically treat the mother, the fetus or placental complications with reduced or absent off-target effects [13].

The development of novel NP-based therapies in pregnancy requires an in-depth understanding of the mechanisms of placental NP transfer and its dependency on distinct particle characteristics and functionalization, among others (Figure 1). To achieve such a detailed mechanistic insight, we need an efficient and predictive screening strategy, including advanced human in vitro and ex vivo placenta models. However, it remains to be investigated whether our current models are suitable for investigating the transport of particulate materials across the human placental barrier as these models have originally been established for and validated with small molecules. Additionally, we need to address how these placental models can be modified in order to make them more representative of the in vivo situation. An increasing number of studies briefly touch on issues with current models but a clear problem definition or more far-reaching suggestions for improvements are scarce.

This review aims to examine and evaluate whether the available studies already allow first conclusions to be drawn if placental NP translocation can be steered by specific NP properties or functionalization. Based on the outcome of our literature search we identify major gaps and give recommendations on how to push the field forward. A prerequisite to achieve meaningful results is the use of predictive models and therefore, we will also briefly describe the existing placental transfer models focusing on their suitability for NP transfer studies and give advice on how to improve these models. 


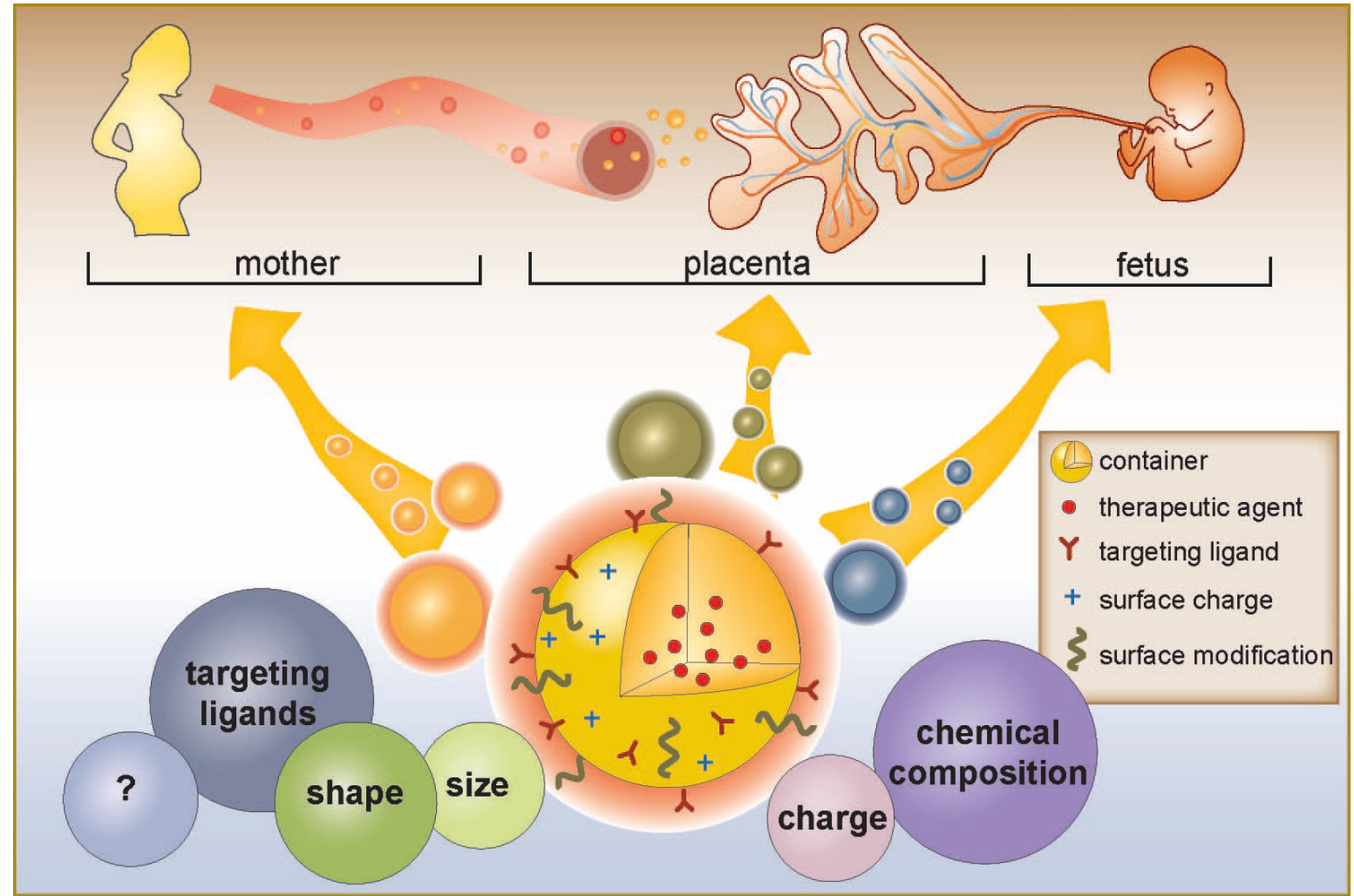

Figure 1: Towards novel nanomedical therapies in pregnancy. Achieving a comprehensive understanding on how NP characteristics such as size, shape, charge, chemical composition and targeting ligands impact on placental accumulation, translocation and biological effects is central to the development of new drug-delivery systems with the objective to preferentially treat the mother, the fetus or placental disorders. The identification of key parameters that allow steering of the particle transfer across the placental barrier is envisaged to greatly reduce off-target effects, which are of particular concern during pregnancy.

\section{Influence of NP characteristics on placental transfer- Is there a trend?}

To gain a deeper understanding of the role of NP characteristics and functionalization in placental NP transfer, the available published data were collected and grouped according to the studied NP properties including size (Table 1), surface charge (Table 2) or shape. Studies which report the absence of placental transfer were also included (Table 3 ) as these particles may have potential for the treatment of maternal disorders. However, we did not consider any placental studies that focused on NP toxicity but did not report on their translocation. This grouping approach was applied to more efficiently identify trends, controversial results, gaps as well as needs for future studies.

\section{Size-dependency}

Most obviously, size seems to play a major role in placental translocation of different types of NPs including gold, polystyrene (PS) beads, silica, quantum dots and poly(lactic-co-glycolic acid) (PLGA) NPs (Table 1). Almost all studies have in common that the amount of transferred NPs was higher for smaller compared to larger NPs. To give one example, the size of PLGA NPs was shown to influence transfer by the BeWo b30 Transwell model with a $25 \%$ higher 
apparent permeability for $146 \mathrm{~nm}$ than for $232 \mathrm{~nm}$ PLGA NPs after $2 \mathrm{~h}$ of exposure [16]. Importantly, the general trend in size-dependent transfer of NPs was observed for all of the applied models independent of the species origin (rodent versus human) or the complexity (in vivo versus ex vivo versus in vitro).

The cutoff size where no or only very limited amounts of NPs were transferred through the placental barrier appears to be highly dependent on the material. In pregnant rats, gold NPs larger than $80 \mathrm{~nm}$ did not cross the placental barrier [17] whereas $519 \mathrm{~nm}$ silicon nanovectors were still measured in fetal organs [18]. For PS particles, the threshold size for maternal to fetal transfer was around 200-300 nm in the ex vivo human placenta perfusion model [19] and around $100 \mathrm{~nm}$ in the BeWo b30 Transwell model [20]. In contrast, transfer of up to $500 \mathrm{~nm}$ PS NPs without apparent size-dependency has been observed in pregnant mice by qualitative fluorescent microscopic analysis of fetal tissues [21]. This high variation in the cutoff sizes suggest that there might be differences in the tightness of the placental barrier for NP passage between the different models and it will be crucial to understand in how far these models are predictive of placental translocation in pregnant women. The qualitative analysis of $\mathrm{SiO}_{2} \mathrm{NP}$ transfer in mice revealed a similar cutoff size as for PS NPs. $70 \mathrm{~nm}$ but not $300 \mathrm{~nm}$ or $1000 \mathrm{~nm}$ particles were detected in fetal mouse tissues [22]. In contrast, $519 \mathrm{~nm}$ silicon nanovectors were still detected in fetal rat tissues [18]. But even if the same $25 \mathrm{~nm} \mathrm{SiO} 2$ NPs were used in the same BeWo b30 Transwell model [23, 24], major differences were observed in the translocation rates $\left(P_{\mathrm{e}}: 1.5 \times 10^{-6} \mathrm{~cm} / \mathrm{s}[24]\right.$ versus $\left.0.018 \mathrm{~cm} / \mathrm{s}[23]\right)$. It should be noted that the cut-off size for placental translocation of NP might vary significantly between the applied models, especially due to species-specific differences (mice, rats, humans). This clearly shows the need for standardized procedures with regard to NP handling and standardization of the different models to obtain comparable results across different labs.

Interestingly, when looking at the lower size range minor changes in the primary particle size seem to have major effects on placental barrier crossing. For core/shell CdTe/CdS NPs, Chu et al found a slightly increased transfer of $1.67 \mathrm{~nm}$ compared to $3.21 \mathrm{~nm}$ NPs [25]. However, the quantification of cadmium-based NPs is notoriously difficult since most analytical methods do not distinguish between free cadmium ions released from quantum dots and quantum dot NPs. This discrimination can probably only be achieved by a thorough characterization of the NP dissolution behavior in the appropriate biological medium combined with the use of advanced analytical methods that are capable of distinguishing ionic and particulate materials with high resolution, such as single-particle ICP-MS or asymmetrical flow field flow fractionation ICP-MS (AF4-ICP-MS) [26, 27].

Finally, there were also a few publications confirming translocation of only one particular NP size such as $5.6 \mathrm{~nm}$ PAMAM dendrimers [28], <10 nm C C4-labelled fullerenes [29], 25-70 nm $\mathrm{TiO}_{2} \mathrm{NPs}[22,30], 20 \mathrm{~nm}$ ultrasmall superparamagnetic iron oxide particles (USPIO) [31] and $50 \mathrm{~nm}$ Ag NPs [32]. Although size-dependency was not explicitly addressed in these studies they were included here because they collectively provide further evidence that relatively small NPs $(<100 \mathrm{~nm})$ of the majority of material classes can cross the placental barrier. Placental 
translocation was also observed for CNTs with length up to a few micrometers [33, 34]. However, as CNTs are non-rigid structures and often are highly entangled, it is challenging to draw any conclusions on size-dependent transfer.

Table 1. Summary of NP transfer studies across the placental barrier in dependence on different sizes.

\begin{tabular}{|c|c|c|c|c|c|c|}
\hline $\begin{array}{l}\text { Size } \\
(\mathrm{nm})\end{array}$ & NP type & $\begin{array}{l}\text { Coating/ } \\
\text { labelling }\end{array}$ & $\begin{array}{l}\text { Z-potential } \\
(\mathrm{mV})\end{array}$ & $\begin{array}{c}\text { Model } \\
\text { (GD, admin) }\end{array}$ & $\begin{array}{c}\text { Transfer } \\
\text { (detection method) }\end{array}$ & Ref \\
\hline $146 \pm 2^{5}$ & PLGA & $\begin{array}{l}\text { dexamethasone- } \\
\text { loaded }\end{array}$ & $-64.3 \pm 1.3^{1}$ & $\begin{array}{l}\text { BeWo b30 } \\
\text { Transwell }\end{array}$ & $\begin{array}{c}\mathrm{P}_{\mathrm{e}}: 6.0 \times 10^{-5} \pm 1.6 \times 10^{-5} \\
\mathrm{~cm} / \mathrm{s} \text { after } 2 \mathrm{~h}\end{array}$ & 16 \\
\hline $232 \pm 1^{5}$ & PLGA & $\begin{array}{l}\text { dexamethasone- } \\
\text { loaded }\end{array}$ & $-63.1 \pm 1.1^{1}$ & $\begin{array}{l}\text { BeWo b30 } \\
\text { Transwell }\end{array}$ & $\begin{array}{c}\mathrm{P}_{\mathrm{e}}: 4.8 \times 10^{-5} \pm 1.6 \times 10^{-5} \\
\mathrm{~cm} / \mathrm{s} \text { after } 2 \mathrm{~h}\end{array}$ & \\
\hline $145 \pm 1^{5}$ & PLGA & -/coumarin-6 & $-46.7 \pm 1.7^{1}$ & $\begin{array}{l}\text { BeWo b30 } \\
\text { Transwell }\end{array}$ & $\mathrm{P}_{\mathrm{e}}: \sim 6 \times 10^{-6} \mathrm{~cm} / \mathrm{s}$ after $2 \mathrm{~h}$ & \\
\hline $196 \pm 2^{5}$ & PLGA & -/coumarin-6 & $-47.8 \pm 1.1^{1}$ & $\begin{array}{l}\text { BeWo b30 } \\
\text { Transwell }\end{array}$ & $\mathrm{P}_{\mathrm{e}}: \sim 3 \times 10^{-6} \mathrm{~cm} / \mathrm{s}$ after $2 \mathrm{~h}$ & \\
\hline 1.4 & $\mathrm{Au}$ & $\mathrm{S}-\mathrm{TPP} /{ }^{198} \mathrm{Au}$ & $-20 \pm 2.4^{1}$ & rat $(18$, i.v. $)$ & $\begin{array}{c}30 \mathrm{ng}\left(1.2 \times 10^{11} \mathrm{NPs}\right) \text { after } \\
24 \mathrm{~h}\end{array}$ & 17 \\
\hline 18 & $\mathrm{Au}$ & $\mathrm{S}-\mathrm{TPP} /{ }^{198} \mathrm{Au}$ & $-22.8 \pm 3.1^{1}$ & rat $(18$, i.v. $)$ & $\begin{array}{c}0.12 \mathrm{ng}\left(2.4 \times 10^{6} \mathrm{NPs}\right) \\
\text { after } 24 \mathrm{~h}\end{array}$ & \\
\hline 80 & $\mathrm{Au}$ & $\mathrm{S}-\mathrm{TPP} /{ }^{198} \mathrm{Au}$ & $-27.1 \pm 1.3^{1}$ & rat $(18$, i.v. $)$ & $<$ LOD after $24 \mathrm{~h}$ & \\
\hline 519 & $\mathrm{Si}$ & -/fluorescein & $-31.4 \pm 0.8^{2}$ & rat $(20$, i.v. $)$ & $\begin{array}{c}5.93 \pm 0.67 \mu \mathrm{g} / \mathrm{g} \text { tissue } \\
\text { after } 4 \mathrm{~h}\end{array}$ & 18 \\
\hline 834 & $\mathrm{Si}$ & -/fluorescein & $\begin{array}{l}-41.5 \pm \\
0.28^{2}\end{array}$ & rat $(20$, i.v. $)$ & no transfer & \\
\hline 1000 & $\mathrm{Si}$ & -/fluorescein & $-53.2 \pm 1.1^{2}$ & rat $(20$, i.v. $)$ & no transfer & \\
\hline 70 & $\mathrm{SiO}_{2}$ & $-1-$ & $-52.7^{1}$ & $\begin{array}{c}\text { mouse }(16,17, \\
\text { i.v. })\end{array}$ & $\begin{array}{l}\text { NPs in placenta and fetus } \\
\text { after } 48 \mathrm{~h} \text { (qualitative) }\end{array}$ & 22 \\
\hline 300 & $\mathrm{SiO}_{2}$ & $-1-$ & $-62.1^{1}$ & $\begin{array}{c}\text { mouse }(16,17, \\
\text { i.v. })\end{array}$ & $\begin{array}{l}\text { NPs not detected in } \\
\text { placenta and fetus after } \\
48 \mathrm{~h} \text { (qualitative) }\end{array}$ & \\
\hline 1000 & $\mathrm{SiO}_{2}$ & $-1-$ & $-67.0^{1}$ & $\begin{array}{c}\text { mouse }(16,17, \\
\text { i.v. })\end{array}$ & $\begin{array}{l}\text { NPs not detected in } \\
\text { placenta and fetus after } \\
48 \mathrm{~h} \text { (qualitative) }\end{array}$ & \\
\hline $15-30$ & $\mathrm{SiO}_{2}$ & -/rhodamine & $-20^{1}$ & $\begin{array}{l}\text { BeWo b30 } \\
\text { Transwell }\end{array}$ & $\begin{array}{c}26.2 \pm 0.8 \% \text { of ID; } P_{e}: \\
0.018 \pm 0.007 \mathrm{~cm} / \mathrm{s} \text { after } 6 \mathrm{~h}\end{array}$ & 23 \\
\hline $25-50$ & $\mathrm{SiO}_{2}$ & -/rhodamine & $-22^{1}$ & $\begin{array}{l}\text { BeWo b30 } \\
\text { Transwell }\end{array}$ & $\begin{array}{c}29.0 \pm 8.9 \% \text { of ID; } P_{e}: \\
0.017 \pm 0.009 \mathrm{~cm} / \mathrm{s} \text { after } 6 \mathrm{~h}\end{array}$ & \\
\hline 25 & $\mathrm{SiO}_{2}$ & -/rhodamine & n.d. & $\begin{array}{l}\text { BeWo b30 } \\
\text { Transwell }\end{array}$ & $\begin{array}{c}P_{e}: 1.54 \times 10^{-6} \pm 1.56 \times 10^{-6} \\
\mathrm{~cm} / \mathrm{s} \text { after } 24 \mathrm{~h}\end{array}$ & 24 \\
\hline 25 & $\mathrm{SiO}_{2}$ & -/rhodamine & n.d. & $\begin{array}{l}\text { human term } \\
\text { placenta } \\
\text { perfusion }\end{array}$ & $4.2 \% \pm 4.9 \%$ of ID after $6 h$ & \\
\hline 50 & $\mathrm{SiO}_{2}$ & -/rhodamine & n.d. & $\begin{array}{l}\text { human term } \\
\text { placenta } \\
\text { perfusion }\end{array}$ & $4.6 \% \pm 2.4 \%$ of ID after $6 h$ & \\
\hline 50 & PS & -/yellow & $\begin{array}{l}-58.7 \pm \\
2.26^{1}\end{array}$ & $\begin{array}{l}\text { human term } \\
\text { placenta } \\
\text { perfusion }\end{array}$ & $8.90 \pm 1.80 \mu \mathrm{g} / \mathrm{mL}$ after $3 \mathrm{~h}$ & 19 \\
\hline 80 & PS & -/Fluoresbrite ${ }^{\circledR}$ & $\begin{array}{l}-56.4 \pm \\
2.12^{1}\end{array}$ & $\begin{array}{l}\text { human term } \\
\text { placenta } \\
\text { perfusion }\end{array}$ & $7.47 \pm 1.77 \mu \mathrm{g} / \mathrm{mL}$ after $3 \mathrm{~h}$ & \\
\hline
\end{tabular}




\begin{tabular}{|c|c|c|c|c|c|c|}
\hline 240 & PS & -/yellow & $\begin{array}{l}-32.7 \pm \\
0.78^{1}\end{array}$ & $\begin{array}{l}\text { human term } \\
\text { placenta } \\
\text { perfusion }\end{array}$ & $2.03 \pm 0.29 \mu \mathrm{g} / \mathrm{mL}$ after $3 \mathrm{~h}$ & \\
\hline 500 & PS & -/Fluoresbrite ${ }^{\circledR}$ & $\begin{array}{l}-42.3 \pm \\
0.49^{1}\end{array}$ & $\begin{array}{l}\text { human term } \\
\text { placenta } \\
\text { perfusion }\end{array}$ & $0.31 \pm 0.21 \mu \mathrm{g} / \mathrm{mL}$ after $3 \mathrm{~h}$ & \\
\hline 50 & PS latex & -/Fluoresbrite ${ }^{\circledR}$ & n.d. & $\begin{array}{l}\text { BeWo b30 } \\
\text { Transwell }\end{array}$ & $\begin{array}{c}3.5 \% \text { of ID after } 24 \mathrm{~h} ; \mathrm{P}_{\mathrm{e}}: \\
3.8 \pm 1.1 \times 10^{-5} \mathrm{~cm} / \mathrm{s} \text { after } \\
2 \mathrm{~h}\end{array}$ & 20 \\
\hline 100 & PS latex & -/Fluoresbrite ${ }^{\circledR}$ & n.d. & $\begin{array}{l}\text { BeWo b30 } \\
\text { Transwell }\end{array}$ & $\begin{array}{c}0.6 \% \text { of ID after } 24 \mathrm{~h} ; \mathrm{P}_{\mathrm{e}}: \\
1.8 \pm 0.7 \times 10^{-5} \mathrm{~cm} / \mathrm{s} \text { after } \\
2 \mathrm{~h}\end{array}$ & \\
\hline 20 & PS & $\mathrm{COOH} /$ yellow green & n.d. & mouse $(17$, i.v. $)$ & $\begin{array}{l}\text { NPs in placenta and fetus } \\
\text { after } 4 \mathrm{~h} \text { (qualitative) }\end{array}$ & 21 \\
\hline 40 & PS & $\mathrm{COOH} /$ yellow green & n.d. & mouse (17, i.v.) & $\begin{array}{l}\text { NPs in placenta and fetus } \\
\text { after } 4 \mathrm{~h} \text { (qualitative) }\end{array}$ & \\
\hline 100 & PS & $\mathrm{COOH} /$ yellow green & n.d. & mouse $(17$, i.v. $)$ & $\begin{array}{l}\text { NPs in placenta and fetus } \\
\text { after } 4 \mathrm{~h} \text { (qualitative) }\end{array}$ & \\
\hline 200 & PS & $\mathrm{COOH} /$ yellow green & n.d. & mouse $(17$, i.v. $)$ & $\begin{array}{l}\text { NPs in placenta and fetus } \\
\text { after } 4 \mathrm{~h} \text { (qualitative) }\end{array}$ & \\
\hline 500 & PS & $\mathrm{COOH} /$ yellow green & n.d. & mouse $(17$, i.v. $)$ & $\begin{array}{l}\text { NPs in placenta and fetus } \\
\text { after } 4 \mathrm{~h} \text { (qualitative) }\end{array}$ & \\
\hline $\begin{array}{l}1.67 \pm \\
0.29\end{array}$ & $\begin{array}{l}\text { CdTe/CdS } \\
\text { QDs }\end{array}$ & MPA/- & n.d. & $\begin{array}{l}\text { mouse }(\sim 20-22 \text {, } \\
\text { i.v. })\end{array}$ & $20.69 \pm 7.23 \mathrm{ng} \mathrm{Cd} / \mathrm{g}$ tissue & 25 \\
\hline $\begin{array}{c}2.59 \pm \\
0.43\end{array}$ & $\begin{array}{l}\text { CdTe/CdS } \\
\text { QDs }\end{array}$ & MPA/- & n.d. & $\begin{array}{l}\text { mouse }(\sim 20-22, \\
\text { i.v. })\end{array}$ & $14.22 \pm 1.97 \mathrm{ng} \mathrm{Cd} / \mathrm{g}$ tissue & \\
\hline $\begin{array}{c}3.21 \pm \\
0.32\end{array}$ & $\begin{array}{l}\text { CdTe/CdS } \\
\text { QDs }\end{array}$ & MPA/- & n.d. & $\begin{array}{l}\text { mouse }(\sim 20-22, \\
\text { i.v. })\end{array}$ & $13.20 \pm 3.24 \mathrm{ng} \mathrm{Cd} / \mathrm{g}$ tissue & \\
\hline $\begin{array}{c}0.5-2 \\
\mu \mathrm{m} \times 1- \\
2 \mathrm{~nm}\end{array}$ & SWCNT & amine/- & $-1.3^{5}$ & $\begin{array}{l}\text { mouse (10.5, } \\
12.5,15.5, \text { i.v. })\end{array}$ & $\begin{array}{c}20 \% \text { of ID/g in fetal liver } \\
5 \% \text { of ID/g in placenta after } \\
48 \mathrm{~h}\end{array}$ & 33 \\
\hline $\begin{array}{c}0.5-2 \\
\mu \mathrm{m} x<8 \\
\mathrm{~nm}\end{array}$ & MWCNT & amine/- & $-1^{5}$ & $\begin{array}{l}\text { mouse }(10.5 \\
12.5,15.5, \text { i.v. }\end{array}$ & $\begin{array}{c}20 \% \text { of ID/g in fetal liver } \\
5 \% \text { of ID/g in placenta after } \\
48 \mathrm{~h}\end{array}$ & \\
\hline $\begin{array}{c}0.5-2 \\
\mu \mathrm{m} x \\
20-30 \\
\mathrm{~nm}\end{array}$ & MWCNT & amine/- & $-1.9^{5}$ & $\begin{array}{l}\text { mouse }(10.5 \\
12.5,15.5, \text { i.v. }\end{array}$ & $\begin{array}{c}20 \% \text { of ID } / g \text { in fetal liver } \\
5 \% \text { of ID/g in placenta after } \\
48 \mathrm{~h}\end{array}$ & \\
\hline $\begin{array}{c}0.5-2 \\
\mu \mathrm{m} \times 50 \\
\mathrm{~nm}\end{array}$ & MWCNT & amine/- & $-1.5^{5}$ & $\begin{array}{l}\text { mouse }(10.5 \\
12.5,15.5, \text { i.v. }\end{array}$ & $\begin{array}{c}20 \% \text { of ID/g in fetal liver } \\
5 \% \text { of ID/g in placenta after } \\
48 \mathrm{~h}\end{array}$ & \\
\hline 5.6 & G4PAMAM & $\begin{array}{l}\text { neutral hydroxyl } \\
\text { groups/Alexa } 488\end{array}$ & $-8.23^{3}$ & $\begin{array}{l}\text { human term } \\
\text { placenta } \\
\text { perfusion }\end{array}$ & $\begin{array}{c}\sim 2.26 \pm 0.12 \mu \mathrm{g} / \mathrm{mL} \text { after } \\
5.5 \mathrm{~h}\end{array}$ & 28 \\
\hline$<10$ & fullerenes & $-/^{14} \mathrm{C}$ radioactive & n.d. & rat $(15$, i.v. $)$ & $\begin{array}{c}0.872 \pm 0.213 \% \text { of ID after } \\
24 \mathrm{~h}\end{array}$ & 29 \\
\hline $25-70$ & $\mathrm{TiO}_{2}$ & $-/-$ & n.d. & $\begin{array}{c}\text { mouse } \\
(3,7,10,14 \\
\text { subcutan })\end{array}$ & $\begin{array}{c}\text { NPs in fetal brain and testis } \\
\text { (qualitative) }\end{array}$ & 30 \\
\hline 35 & $\mathrm{TiO}_{2}$ & $-/-$ & $-22.5^{1}$ & $\begin{array}{l}\text { mouse }(16,17, \\
\text { i.v.) }\end{array}$ & $\begin{array}{l}\text { NPs in placenta and fetus } \\
\text { after } 48 \mathrm{~h} \text { (qualitative) }\end{array}$ & 22 \\
\hline 20 & USPIO & $\begin{array}{l}\mathrm{COOH}, \text { conjugated } \\
\text { to anti-C3 Antibodies }\end{array}$ & n.d. & mouse (15/ i.v.) & $\begin{array}{l}\text { NPs in placenta and fetal } \\
\text { brain after } 12-24 \mathrm{~h} \\
\text { (qualitative) }\end{array}$ & 31 \\
\hline 50 & $\mathrm{Ag}$ & $-/-$ & $-29^{4}$ & mouse $(7-9$, i.v. $)$ & $0.008-0.009 \%$ of ID & 32 \\
\hline $\begin{array}{l}1-2 \mu \mathrm{m} \\
\times 10- \\
30 \mathrm{~nm}\end{array}$ & oMWCNTs & $-{ }^{-99 \mathrm{~m} \mathrm{Tc}}$ & - & mouse $(17$, i.v. $)$ & $\sim 0.5 \%$ of ID $/ \mathrm{g}$ after $2-24 \mathrm{~h}$ & 34 \\
\hline
\end{tabular}

NP size is given as the primary particle size unless in few cases where only the NP hydrodynamic diameter determined by DLS were reported (5). Zetapotential was either measured in $\mathrm{H}_{2} \mathrm{O}(1)$, saline (2), maternal perfusate (3) or sodium citrate dihydrate (4). 
GD, gestational day; ID, initial dose; i.v., intravenous injection; LOD, limit of detection; MPA, 3-mercaptopropionic acid; n.d., not determined); $P_{e}$, permeability coefficient; PEG, polyethylene glycol; PLGA, poly(d,I-lactide-

coglycolide); PS, Polystyrene; QDs, quantum dots; S-TPP, sulfonated triphenylphosphine

\section{Surface charge-dependency}

Besides size, different surface charges have been proposed to influence placental barrier crossing (Table 2). In general, it is often assumed that cellular uptake and translocation of negatively charged NPs is less likely to happen compared to neutral or positively charged NPs, as negatively charged particles may be electrostatically repelled from the negatively charged cell membrane [35]. For example, Grafmueller et al. showed in the ex vivo perfusion model that transfer of plain $50 \mathrm{~nm}$ PS particles was significantly higher than of $50 \mathrm{~nm} \mathrm{COOH}-\mathrm{PS}$ particles [36]. A similar but not significant trend was also observed for plain $220 \mathrm{~nm}$ and $290 \mathrm{~nm} \mathrm{COOH}-$ PS beads [36]. And while no particle translocation was observable for negatively charged poly(acrylic acid)-coated iron oxide NPs, a substantial increase in iron content was detected in the fetal liver of newborn mice after exposure to positively charged iron oxide NPs coated with polyethyleneimine [37]. However, it remains unclear if this increase in total iron content was from transferred NPs $\left(\mathrm{Fe}_{2} \mathrm{O}_{3}\right)$ or $\mathrm{Fe}^{3+}$. In a study in pregnant mice, already slight differences in the surface charge of gold NPs obtained by functionalization with ferritin, PEG or citrate led to a charge-dependent transfer of the particles with the lowest transfer observed for the most negatively charged particles [38]. Interestingly, there are also few examples that describe a higher transfer for particles with a more negative charge. Around $25 \%$ of the initial dose of iron oxide NPs with a sodium oleate micelle coating and a negative zeta potential was passing through the BeWo b30 Transwell model while plain iron oxide NPs were not identified in the basolateral compartment [23]. However, the latter particles apparently formed agglomerates, which presumably then blocked the pores of the membrane thus making it difficult to draw any conclusion on a charge-dependent transfer. In addition, sodium oleate functionalization renders the particles more hydrophobic hence potentially introducing a confounding factor. Another study using the BeWo b30 Transwell model observed that the apparent permeability of coumarin-6-loaded PLGA NPs was one order of magnitude lower as for dexamethasoneloaded PLGA NPs even though the zeta potential of coumarin-6-loaded NPs was higher [16]. Since the plain PLGA particles were not modified with functional groups, the different surface charges were probably due to the incorporated drugs. As long as it is not clear in how far these drugs may induce additional unexpected effects on NP translocation, it might be advisable to focus such mechanistic translocation studies on particles that are not loaded with any pharmaceutical compounds. Increased transfer of negatively charged particles was also observed in a study using positively and negatively charged PS particles [39]. However, there was an apparent conflict within the study as two PS NPs with a very similar negative charge showed completely different transfer behavior (high versus no transfer). The authors suggested that this difference was due to different chemical compositions of the coatings used by the two providers, indicating that the effect cannot solely be explained by surface charge. Finally, 70 $\mathrm{nm}$ plain, $\mathrm{NH}_{2}$ - and $\mathrm{COOH}-\mathrm{SiO}_{2} \mathrm{NPs}$ were found to cross the placental barrier in mice as 
confirmed by TEM micrographs [22]. Since a quantitative analysis is lacking, this study does not provide further insight into surface charge-dependent placental NP transfer. Despite the general assumption that positively charged particles show higher translocation rates than negatively charged particles, we could not clearly identify this trend in the available literature. It should be noted that the induction of charges by functionalization of the particles is often connected with changes in other surface characteristics such as hydrophobicity/hydrophilicity, among others, which can further impact the particle translocation. To resolve the impact of charge-dependency on NP translocation more studies are required including a larger variety of NPs.

Table 2. Summary of NP transfer studies across the placental barrier in dependence on different surface charges.

\begin{tabular}{|c|c|c|c|c|c|c|}
\hline Size $(\mathrm{nm})$ & NP type & $\begin{array}{l}\text { Coating/ } \\
\text { labelling }\end{array}$ & $\begin{array}{c}\zeta \text {-potential } \\
(\mathrm{mV})\end{array}$ & $\begin{array}{c}\text { Model } \\
\text { (GD, admin) }\end{array}$ & $\begin{array}{c}\text { Transfer } \\
\text { (detection method) }\end{array}$ & Ref \\
\hline $43.7 \pm 8$ & PS & $\begin{array}{c}\text { neutral/yellow } \\
\text { green }\end{array}$ & $\begin{array}{c}-19.8 \pm \\
4.0^{2}\end{array}$ & $\begin{array}{l}\text { human term } \\
\text { placenta } \\
\text { perfusion }\end{array}$ & $\begin{array}{c}13.7 \pm 8.4 \% \text { of ID after } \\
6 \mathrm{~h}\end{array}$ & 36 \\
\hline $44.1 \pm 7.1$ & PS & $\begin{array}{l}\mathrm{COOH} / \text { yellow } \\
\text { green }\end{array}$ & $\begin{array}{l}-34.7 \pm \\
7.1^{2}\end{array}$ & $\begin{array}{l}\text { human term } \\
\text { placenta } \\
\text { perfusion }\end{array}$ & $1.4 \pm 0.5 \%$ of ID after $6 \mathrm{~h}$ & \\
\hline $220.5 \pm 5.1$ & PS & $\begin{array}{c}\text { neutral/yellow } \\
\text { green }\end{array}$ & $\begin{array}{l}-20.5 \pm \\
2.7^{2}\end{array}$ & $\begin{array}{l}\text { human term } \\
\text { placenta } \\
\text { perfusion }\end{array}$ & $2.4 \pm 0.7 \%$ of ID after $6 \mathrm{~h}$ & \\
\hline $289.4 \pm 10.2$ & PS & $\begin{array}{l}\mathrm{COOH} / \text { yellow } \\
\text { green }\end{array}$ & $\begin{array}{c}-55.6 \pm \\
6.1^{2}\end{array}$ & $\begin{array}{l}\text { human term } \\
\text { placenta } \\
\text { perfusion }\end{array}$ & $1.2 \pm 0.7 \%$ of ID after $6 \mathrm{~h}$ & \\
\hline $56.5 \pm 3.02^{4}$ & $\begin{array}{c}\text { PS } \\
\text { (Magsphere) }\end{array}$ & $\mathrm{NH}_{2} /$ red & $51.0^{1}$ & $\begin{array}{l}\text { BeWo b30 } \\
\text { Transwell }\end{array}$ & $\begin{array}{c}P_{\text {app }}: 0.3 \times 10^{-6} \mathrm{~cm} / \mathrm{s} \text { after } \\
24 \mathrm{~h}\end{array}$ & 39 \\
\hline $52.4 \pm 0.1^{4}$ & $\begin{array}{c}\text { PS } \\
\text { (Polyscience) }\end{array}$ & $\begin{array}{l}\mathrm{COOH} / \text { yellow } \\
\text { green }\end{array}$ & $-58.3^{1}$ & $\begin{array}{l}\text { BeWo b30 } \\
\text { Transwell }\end{array}$ & $\begin{array}{c}P_{\text {app }}: 13 \times 10^{-6} \mathrm{~cm} / \mathrm{s} \text { after } \\
24 \mathrm{~h}\end{array}$ & \\
\hline $50.4 \pm 1.74^{4}$ & $\begin{array}{c}\text { PS } \\
\text { (Magsphere) }\end{array}$ & $\mathrm{COOH} / \mathrm{red}$ & $-55.5^{1}$ & $\begin{array}{l}\text { BeWo b30 } \\
\text { Transwell }\end{array}$ & no detection after $24 \mathrm{~h}$ & \\
\hline $28^{4}$ & $\mathrm{Fe}_{\mathrm{x}} \mathrm{O}_{\mathrm{y}}$ & PAA/- & $-52^{1}$ & $\begin{array}{l}\text { mouse }(9-16 \\
\text { ip) }\end{array}$ & $\begin{array}{l}\text { no accumulation of iron } \\
\text { in fetus }\end{array}$ & 37 \\
\hline $30^{4}$ & $\mathrm{Fe}_{\mathrm{x}} \mathrm{O}_{\mathrm{y}}$ & $\mathrm{PEl} /-$ & $51^{1}$ & $\begin{array}{l}\text { mouse }(9-16 \\
\text { ip) }\end{array}$ & $\begin{array}{l}\text { sign. accumulation of } \\
\text { iron in fetal liver only } \\
\text { after multiple doses ( } 8 \\
\text { consec. days) }\end{array}$ & \\
\hline $10 \times 7$ & $\mathrm{Fe}_{3} \mathrm{O}_{4}$ & neutral/- & $-2.8^{1}$ & $\begin{array}{l}\text { BeWo b30 } \\
\text { Transwell }\end{array}$ & no transport after $24 \mathrm{~h}$ & 23 \\
\hline $9 \times 7$ & $\mathrm{Fe}_{3} \mathrm{O}_{4}$ & Na-oleate micelle/- & $-31.9^{1}$ & $\begin{array}{l}\text { BeWo b30 } \\
\text { Transwell }\end{array}$ & $\begin{array}{c}24.1 \pm 3.0 \% \text { of ID; } P_{\mathrm{e}}: \\
0.017 \pm 0.002 \mathrm{~cm} / \mathrm{s} \text { after } \\
6 \mathrm{~h}\end{array}$ & \\
\hline$\sim 13$ & $\mathrm{Au}$ & ferritin/- & $-1.6^{3}$ & $\begin{array}{l}\text { mouse (7.5 } \\
\text { or } 11.5 \text {, i.v.) }\end{array}$ & $\begin{array}{c}\text { E7.5: } \sim 0.8 \% \text { of ID; } \\
\text { E11.5: } \sim 0.06 \% \text { after } 5 \mathrm{~h}\end{array}$ & 38 \\
\hline$\sim 13$ & $\mathrm{Au}$ & PEG/- & $-6.0^{3}$ & $\begin{array}{l}\text { mouse ( } 7.5 \\
\text { or } 11.5 \text {, i.v.) }\end{array}$ & $\begin{array}{c}\text { E7.5: } \sim 0.6 \% \text { of ID; } \\
\text { E11.5: } \sim 0.02 \% \text { after } 5 \mathrm{~h}\end{array}$ & \\
\hline$\sim 13$ & $\mathrm{Au}$ & citrate/- & $-17.0^{3}$ & $\begin{array}{l}\text { mouse }(7.5 \\
\text { or } 11.5 \text {, i.v. })\end{array}$ & $\begin{array}{c}\text { E7.5: } \sim 0.1 \% \text { of ID; } \\
\text { E11.5: } \sim 0.02 \% \text { after } 5 \mathrm{~h}\end{array}$ & \\
\hline $145 \pm 1^{4}$ & PLGA & -/coumarin-6 & $\begin{array}{c}-46.7 \pm \\
1.7^{1}\end{array}$ & $\begin{array}{l}\text { BeWo b30 } \\
\text { Transwell }\end{array}$ & $\begin{array}{c}\mathrm{P}_{\mathrm{e}}: \sim 6 \times 10^{-6} \mathrm{~cm} / \mathrm{s} \text { after } \\
2 \mathrm{~h}\end{array}$ & 16 \\
\hline $146 \pm 2^{4}$ & PLGA & $\begin{array}{c}\text { contains } \\
\text { dexamethasone }\end{array}$ & $\begin{array}{c}-64.3 \pm \\
1.3^{1}\end{array}$ & $\begin{array}{l}\text { BeWo b30 } \\
\text { Transwell }\end{array}$ & $\begin{array}{c}\mathrm{P}_{\mathrm{e}}: 6.0 \times 10^{-5} \pm 1.6 \times \\
10^{-5} \mathrm{~cm} / \mathrm{s} \text { after } 2 \mathrm{~h}\end{array}$ & \\
\hline
\end{tabular}




\begin{tabular}{|c|c|c|c|c|c|c|}
\hline 70 & $\mathrm{SiO}_{2}$ & $-/-$ & $-52.7^{1}$ & $\begin{array}{c}\text { mouse } \\
(16,17, \text { i.v. })\end{array}$ & $\begin{array}{l}\text { NPs in placenta and } \\
\text { fetus after } 48 \mathrm{~h} \\
\text { (qualitative) }\end{array}$ & 22 \\
\hline 70 & $\mathrm{SiO}_{2}$ & $\mathrm{COOH} /-$ & $-76.3^{1}$ & $\begin{array}{c}\text { mouse } \\
(16,17, \text { i.v. })\end{array}$ & $\begin{array}{l}\text { NPs in placenta and } \\
\text { fetus after } 48 \mathrm{~h} \\
\text { (qualitative) }\end{array}$ & \\
\hline 70 & $\mathrm{SiO}_{2}$ & $\mathrm{NH}_{2} /-$ & $-29.0^{1}$ & $\begin{array}{c}\text { mouse } \\
(16,17, \text { i.v. })\end{array}$ & $\begin{array}{l}\text { NPs in placenta and } \\
\text { fetus after } 48 \mathrm{~h} \\
\text { (qualitative) }\end{array}$ & \\
\hline
\end{tabular}

NP size is given as the primary particle size unless in few cases where only the NP hydrodynamic diameter determined by DLS were reported (4). Zetapotential was either measured in $\mathrm{H}_{2} \mathrm{O}$ (1), $\mathrm{NaCl}$ (2) or PBS (3).

GD, gestational day; ID, initial dose; ip, intraperitoneal; i.v., intravenous injection; LOD, limit of detection; MPA, 3mercaptopropionic acid; $n . d$., not determined; PAA, poly(acrylicacid); $P_{e}$, permeability coefficient; $P_{a p p}$, apparent permeability (= $\mathrm{P}_{\mathrm{e}}$ but no correction for blank); PEG, polyethylene glycol; PEI, polyethyleneimine; PLGA, poly(d,Ilactide-coglycolide); PS, Polystyrene; QDs, quantum dots

\section{Shape-dependency}

To date, shape-dependent NP translocation has not been directly evaluated for the placental barrier but may be of interest especially when considering recent studies showing a shapedependent uptake of different NPs in conventional 2D cell cultures [40, 41]. Especially antigensampling cells such as macrophages are able to recognize the shape of different NPs. Recently it has been shown that the uptake of different silica nanoparticle geometries [42], as well as of fiber-shaped particles and chain-forming bacteria by macrophages was dependent on the orientation of the particles to the cellular surface $[43,44]$. Therefore it is expected that shape might have a significant impact on the translocation behavior. Although maternal to fetal transfer has been observed for spherical as well as for fiber-shaped NPs [33, 34], the influence of NP shape on placental translocation remains largely unknown and deserves further investigations. The emergence of $2 \mathrm{D}$ materials with sheet-like geometry such as graphene oxide and their potential biomedical application [43-45] further increases the diversity of nanomaterials, which can interact with biological barriers such as the placental barrier. A systematic approach using well-defined NP libraries with controlled sizes and shapes may be very effective to understand whether different shapes can provide an effective means to preferentially target the placenta, maternal or fetal circulation.

\section{No placental transfer}

A common problem for the quantification of NP transport is the low sensitivity of many analytical methods. Therefore, the proof of absence of NP transfer is challenging but as new analytical techniques such as AF4-ICP-MS have been developed, it is expected that detection limits will be significantly improved in the near future (see [5] for a recent overview on analytical techniques to quantify and characterize NP translocation).

So far, there are only few studies that suggested the absence of placental translocation (Table 3). No fetal uptake has been observed for $90 \mathrm{~nm}$ fluorescently capped single walled carbon nanotubes (SWCNTs) [8], $46 \mathrm{~nm}$ hydroxyl functionalized SWCNTs [46], 11 and $15 \mathrm{~nm}$ CdO NPs [47], 10, 15 and 30 nm PEG-Au NPs [48], 20 nm and 49 nm Au NPs [49] or $21 \mathrm{~nm}$ UVTitan L181 [50]. Nevertheless, embryotoxicity was observed after both, exposure to CdO NPs [47] and SWCNTs $[8,46]$. However, it was difficult to identify a trend that would help to guide 
the design of novel particles without placental transfer. The type of NP (i.e. CNT, CdO, Au or $\left.\mathrm{TiO}_{2}\right)$ or the size of the particles $(<100 \mathrm{~nm})$ is probably not related to the lack of transfer as placental crossing has been detected for other Au, MWCNT or $\mathrm{TiO}_{2} \mathrm{NPs}$ of similar sizes (Table 1). Since no zeta potential values were provided in the studies summarized in table 3 , no correlation to surface charge was possible either.

We finally want to briefly reflect on some challenges we were facing while trying to allocate each study to an appropriate group and to identify underlying trends. The grouping was not always straightforward due to the fact that size, surface charge and shape were often partially interconnected [51, 52]. Without systematic studies using more appropriate NPs varying in only one individual characteristic (NP libraries), it will not be possible to achieve a comprehensive understanding on the contribution of each factor towards placental transfer. Furthermore, we realized that many aspects with potential relevance for NP transfer such as the role of the protein corona or NP dosimetry remain largely untouched in this particular research field.

Table 3. Summary of NP transfer studies that did not detect transfer of NPs across the placental barrier and accumulation in fetal tissue.

\begin{tabular}{|c|c|c|c|c|c|}
\hline Size (nm) & NP type & $\begin{array}{l}\text { Coating/ } \\
\text { labelling }\end{array}$ & $\begin{array}{c}\text { Model } \\
\text { (GD, admin) }\end{array}$ & $\begin{array}{c}\text { Transfer } \\
\text { (detection method) }\end{array}$ & Ref \\
\hline 90 & SWCNTs & PEG / Seta750 & $\begin{array}{l}\text { mouse ( } 5.5 \text { or } 14.5 \text {, } \\
\text { i.v.) }\end{array}$ & $\begin{array}{c}\text { no transfer detected after } \\
24 \mathrm{~h} \text { (qualitative) }\end{array}$ & 8 \\
\hline $\begin{array}{l}5-30 \mu m x \\
1-2 \mathrm{~nm}\end{array}$ & SWCNTs & hydroxyl group/- & mouse $(9$, gavage $)$ & $\begin{array}{c}\text { no transfer detected on GD } \\
19 \text { (TEM) }\end{array}$ & 46 \\
\hline $11.0 \pm 0.1$ & $\mathrm{CdO}$ & $-/-$ & $\begin{array}{l}\text { mouse (4.5-16.5, } \\
\text { inhalation) }\end{array}$ & $\begin{array}{c}\text { no transfer detected on GD } \\
17.5 \text { (ICP-MS, gAAS) }\end{array}$ & 47 \\
\hline $15.3 \pm 0.1$ & $\mathrm{CdO}$ & $-/-$ & $\begin{array}{l}\text { mouse (4.5-16.5, } \\
\text { inhalation) }\end{array}$ & $\begin{array}{c}\text { no transfer detected at GD } \\
17.5 \text { (ICP-MS, gAAS) }\end{array}$ & \\
\hline 10 & $\mathrm{Au}$ & PEG/- & $\begin{array}{l}\text { human term placenta } \\
\text { perfusion }\end{array}$ & $\begin{array}{l}\text { no transfer detected after } 6 \mathrm{~h} \\
\text { (ICP-MS, qualitative) }\end{array}$ & 48 \\
\hline 15 & $\mathrm{Au}$ & PEG/- & $\begin{array}{l}\text { human term placenta } \\
\text { perfusion }\end{array}$ & $\begin{array}{l}\text { no transfer detected after } 6 \mathrm{~h} \\
\text { (ICP-MS, qualitative) }\end{array}$ & \\
\hline 30 & $\mathrm{Au}$ & PEG/- & $\begin{array}{l}\text { human term placenta } \\
\text { perfusion }\end{array}$ & $\begin{array}{c}\text { no transfer detected after } 18 \\
\text { min (ICP-MS, qualitative) }\end{array}$ & \\
\hline 19.6 & $\mathrm{Au}$ & $-/-$ & mouse (16/17, i.v.) & $\begin{array}{c}\text { no transfer detected after } \\
48 \mathrm{~h} \text { (ICP-MS) }\end{array}$ & 49 \\
\hline 49.3 & $\mathrm{Au}$ & $-/-$ & mouse (16/17, i.v.) & $\begin{array}{c}\text { no transfer detected after } \\
48 \mathrm{~h}(\text { AMG) }\end{array}$ & \\
\hline $20.6 \pm 0.3$ & UV-Titan L181 & polyalcohols/- & $\begin{array}{l}\text { mouse }(8-18 \\
\text { inhalation) }\end{array}$ & $\begin{array}{c}<\text { LOD after } 5 \text { or } 26-27 \text { days } \\
\text { (ICP-MS) }\end{array}$ & 50 \\
\hline
\end{tabular}

AMG, autometallography, gAAS, graphite furnace atomic absorption spectroscopy; GD, gestational day; i.v., intravenous injection; LOD, level of detection; PEG, polyethylene glycol

\section{Future research on placental NP transfer - What are the urgent needs?}

From our grouping approach where we tried to identify characteristics that may enable to control NP translocation at the placental barrier it was evident that a comparison of the available 
literature is very challenging. Reasons for that were insufficient NP characterization data, incomplete study description or different experimental conditions and models, among others. Moreover, many studies focused on potential embryotoxic effects of environmentally relevant NPs whereas translocation was not or only marginally addressed. Therefore, if we want to efficiently push our knowledge on how NP characteristics affect placental uptake, accumulation and transport we have to move on from rather descriptive investigations to more mechanistic transfer studies applying well-characterized NPs varying in either size, shape, surface chemistry or coating. The generation of NP libraries with a high degree of control over NP size or surface charge was already achieved $[53,54]$ but whether such NP libraries can be obtained for each property is unclear.

Besides understanding how NP characteristics influence placental transport, it will be essential to achieve a comprehensive insight into the mechanisms underlying this transfer. Research in this direction is very limited and seemingly controversial results further complicate the picture. Since a variety of different placental transporter inhibitors did not result in any major influence on the translocation of positively or negatively charged $50 \mathrm{~nm}$ PS NPs in the BeWo transfer model, it was concluded that the translocation of these NPs preferentially occurs by passive diffusion [39]. In contrast, bidirectional ex vivo perfusion studies have shown an increased transfer of similar $50 \mathrm{~nm}$ PS particles in the fetal to maternal direction, which suggested the involvement of an active, energy-dependent pathway [36]. Active transport has also been proposed for gold NPs across the mouse placenta due to the increased amount of intracellular vesicles and an up-regulation of clathrin- and caveolin-protein levels in the syncytiotrophoblast and fetal endothelial cells [49]. Predominant accumulation of particles in the syncytiotrophoblast layer has also been described for PS particles of different sizes and surface charge [36] raising the hypothesis that the syncytiotrophoblast may have a pivotal role in the regulation of NP translocation. Besides the use of inhibitors of different receptors, transporters and uptake pathways that can be problematic due to their low specificity or potential cytotoxicity, systems biology approaches such as transcriptomics or proteomics studies may help to identify novel candidates involved in NP translocation across the placental barrier [55]. Furthermore, newly emerging detection methods should be considered for future studies in order to achieve higher sensitivity in NP detection and to obtain accurate and quantitative transfer data (see [5] for an overview).

Another important aspect in NP passage across the human placenta is the role of the biocorona. In a biological environment, NPs will instantly acquire a corona of various biomolecules on their surface, which will have a major impact on their biological behavior [56]. The amount and type of biomolecules adsorbing to a NP surface has been shown to be dependent on the NP characteristics [57]. Therefore, it will be important to understand how the biocorona forms and evolves during the translocation across the placental barrier in particular when we aim to develop nanomedical treatments that target a specific placental or fetal tissue $[58,59]$. It was even proposed that the biocorona itself may be used to direct biological behavior and target diseases instead of chemical grafting [60]. Currently, there is only one in vitro 
placental transfer study that assessed the NP protein corona in cell culture medium [39]. Major differences were mainly found in the amount but not in the nature of the proteins in the corona of the differently charged PS NPs, which is in contrast to a previous work where surface properties had a significant impact on the composition of the protein corona [61]. To better approach the in vivo situation, future studies should try to use more complex, organotypic placental models and include human plasma pre-treatment of the NPs to obtain a relevant protein corona.

Finally, translocation of NPs is likely to be dependent on the different stages of pregnancy [62]. In the first trimester, the placental barrier is very thick in order to protect the developing embryo and becomes thin at term when substantial amounts of nutrients are required to sustain fetal growth [6]. The very sparse studies on NP translocation in early pregnancy use pregnant mice that have been exposed before the placenta has been completely matured ( < gestational day 10) [38]. In general, placental transfer appears to be higher in early pregnancy [8,38]. However, to prevent uncertainties associated with species-specific differences, there is a need for the development of human models for NP transfer studies in early pregnancy. Although ex vivo perfusion of a first trimester placenta is technically feasible, it is not very attractive due to the limited access to such placental tissues. Transwell systems may be a starting point to develop a first trimester model by changing to appropriate cell types representative of early pregnancy. In fact, the ideal placental transfer model would combine some of the following features: a reasonable throughput to test a large set of NPs, suitability for mechanistic NP transfer studies, possibility of extended NP exposure times and a high predictive value for human placental transfer at different stages of pregnancy.

\section{Current placental transfer models - Are they applicable to NP- transfer studies?}

Although a variety of placental models are currently available, only few are suited for translocation studies. These include in vivo transfer studies in rodents, ex vivo perfusion of human term placenta as well as in vitro transfer studies across a trophoblastic monolayer grown on a microporous membrane. Recent reviews comprehensively summarized the existing models and approaches to study the translocation and biological effects of xenobiotics at the human placenta $[5,6,63-66]$. Here, we focused on the suitability of these placental transfer models for NP translocation studies.

\section{In vivo models}

Exposure of pregnant rodents can provide important information on the biodistribution of NPs in a living organism including potential translocation to the fetus. However, the placenta is the most species-specific organ within the class of mammals [67, 68]. Although the placenta fulfills the same functions across species, there are substantial differences in placental development, architecture, function and pathology between rodents and humans. Therefore the extrapolation from animal data to humans is challenging and needs an in-depth evaluation [63]. However, 
obtaining translocation data from pregnant women is difficult and probably only possible for certain therapeutic drugs where non-invasive clinical studies are available. In the case of NPs, an approximate estimation of the predictive value of animal models may be achieved by comparing the transfer of the same NPs during late-gestation in animals and in the ex vivo perfusion of human term placenta.

\section{Ex vivo perfusion model}

The most prominent placental model besides pregnant rodents is the dually perfused ex vivo human placenta model developed in 1967 [69]. This model was continuously improved over the last years $[70,71]$ and has been shown to reliably predict placental transfer of therapeutic drugs at term when adjusting for extra parameters [64]. Since 2008, ex vivo placental perfusion studies have also been carried out with NPs, providing transfer data of high in vivo relevance at least for term pregnancy. It will be challenging but imperative to understand the predictive value of ex vivo perfusions for NP transfer studies as one cannot assume that NPs will exactly behave like small molecule compounds [72]: i) the uptake and biodistribution of NPs can differ significantly as compared to small molecules since the uptake mechanisms of NPs are not yet fully understood and depend on the NP properties, ii) the particle surface can trigger chemical reactions such as the formation of a biocorona, iii) the material properties (crystallinity, shape, allotropic form, etc.) can influence the biological response (for further reading see [51]), iv) the high agglomeration propensity of NPs can have a significant influence on their placental transfer (for further reading see [73]).

In addition, it will be important to exclude any interferences of NPs with the ex vivo perfusion model. We have recently shown that NPs can cause artifacts which were related to particle agglomeration, functionalization and stability of the fluorescent labels (see [74] for a detailed description). To give one example, it has been observed that PS NPs lost a significant amount of their fluorescent marker only after contact with the placental tissue but not in conventional in vitro control experiments [74].

\section{In vitro transfer models}

To enable transfer studies across one or multiple cell layers, placental cells have been grown to confluence on the apical and/or basolateral side of commercial microporous membranes, vitrified collagen membranes $[75,76]$ or the amniotic membrane [77]. While the latter two supports can be used to study the transfer of small molecules such as glucose or small molecule drugs, they will most likely constitute a considerable barrier to the transfer of NPs. Up to now, all in vitro transfer studies with NPs have been performed in the BeWo b30 Transwell model $[16,20,23,24,39]$. This model is capable of predicting similar relative placental transfer compared to the ex vivo placental perfusion model at least for small compounds [78, 79]. However, the transfer rate was much slower in the BeWo b30 Transwell model compared to the ex vivo perfusion system, probably due to the lack of fluid flow [79]. Whether this in vitro model is also predictive for the transfer of NPs is not yet clear [80]. First comparative studies showed a limited transport of $\mathrm{SiO}_{2} \mathrm{NPs}$ [24] as well as a size-dependent transfer of PS NPs in 
both models $[19,20]$. But there are increasing concerns that the commercial microporous membranes may cause major problems for the study of NPs such as blocking of the pores, NP absorption to the membrane material, or very slow transport across the empty membrane [24, 81-83]. It is obvious that pore size is a critical parameter in particle transport that allows or restricts the passage of NPs or NP agglomerates of a certain size. For example, $0.4 \mu \mathrm{m}$ pores extensively restricted the passage of $37 \mathrm{~nm}$ PS NPs [20] or $12 \mathrm{~nm} \mathrm{TiO} 2$ NPs [84] across the membrane. In addition, the distribution of pores in the membrane supports is rather random, which may prevent efficient NP transport across the membrane. Furthermore the surface properties of the membrane may attract or repel NPs e.g. based on their hydrophilicity/hydrophobicity or surface charge, leading to an inefficient transport and accumulation of the particles on the membrane surface [83]. Another shortcoming of the available commercial membranes is their rather large thickness of around 10-20 $\mu \mathrm{m}$, which is in fact comparable to or higher than the thickness of a cell monolayer. Therefore, the ideal situation of short diffusion pathways is not given, and the pores should not be regarded as small holes but rather as relatively long tunnels, which NPs have to cross. Moreover, these tunnels are not strictly perpendicular to the membrane plane but in part follow slightly different angles (Figure 2). This in turn results in an increase in pore channel length and therefore leads to a non-homogeneous travel distance for particles taking different routes through the membrane. In summary, in vitro transfer models will be important to pre-screen the large variety of NPs and to allow mechanistic transfer studies but they need further improvements to increase their predictive value.

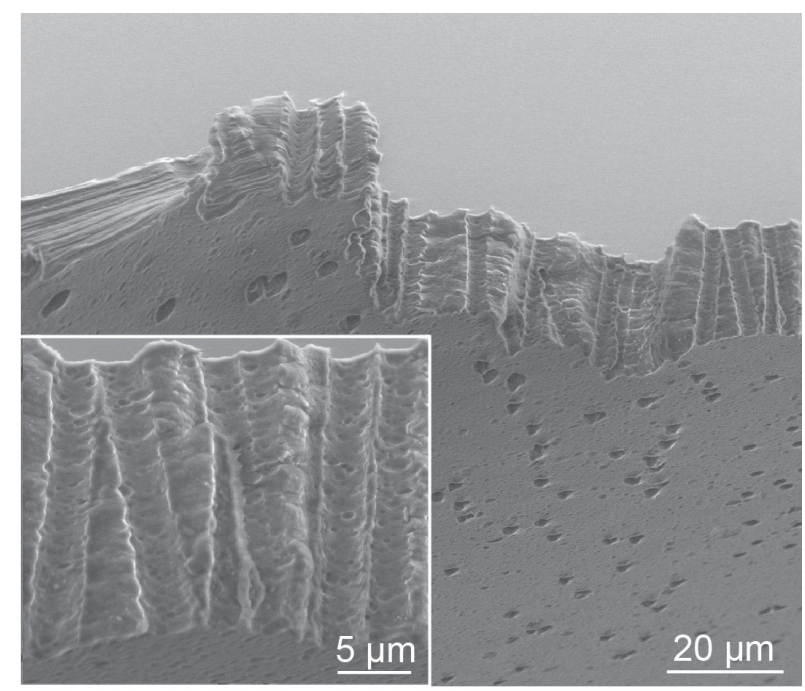

Figure 2: Example of a microporous membrane frequently applied for in vitro translocation studies. SEM images of a PET membrane of ThinCert ${ }^{\mathrm{TM}}$ Cell Culture Inserts (12 Well, Greiner Bio-One GmbH) with $3.0 \mu \mathrm{m}$ pore size showing morphological features such as membrane thickness, course of pore channels and irregular pore distribution. Image courtesy of Dr. Marcus Koch, Head of Physical Analysis at the INM - Leibniz-Institute for New Materials gGmbH, Saarbruecken, Germany.

\section{Next generation placental transfer models - Plenty of room for improvements?}




\section{Ex vivo perfusion model}

To date, each laboratory is using its own customized placental perfusion setup and performs I perfusions with its own modifications of the original protocol [85]. Although many parameters (e.g. glucose consumption, lactate production, $\mathrm{pH}$, oxygen consumption) and control substances (e.g. antipyrine, FITC-dextran) are described to confirm tissue integrity and viability, there is no obligation to use a certain standard set of parameters and controls. Therefore, Mathiesen et al have proposed a set of criteria to confirm successful perfusions [85]. But even better than detailed recommendations for the quality assessment of the individual placental perfusion protocols would be the implementation of standard operating procedures and a more standardized perfusion setup to improve inter-laboratory comparisons and to increase the acceptance of the model by the broader research community and the regulatory bodies.

\section{In vitro transfer models}

Up to now, all in vitro NP translocation studies have been performed with cell lines, which may only have restricted capability to express all necessary functions and transporters or fail to form a functional syncytium. To overcome these limitations, cell lines should be replaced by human placental villous trophoblasts isolated from term placenta. In addition, there is evidence from other barriers that the co-culture of different cell types has a major effect on NP uptake and translocation [84, 86]. Therefore, inclusion of additional cell types (e.g. fetal endothelial cells, villous fibroblasts or Hofbauer macrophages) may allow mimicking of in vivo placental translocation more closely by enabling the interplay of relevant cell types and a more 3D tissuelike organization. For mechanistic studies on NP uptake pathways, development of 3D placental microtissues could be an interesting approach as cells would not be separated by a membrane support [87]. Another strategy to increase the predictability of in vitro transfer models is to move from static to dynamic culture conditions. Most recently it has been demonstrated that trophoblasts respond to fluid shear stress with induction of microvilli formation, changes in $\mathrm{Ca}^{2+}$ influx, in vivo-like localization of the GLUT1 membrane transporter, as well as altered glucose uptake and transport [76].

Furthermore, there is a need for improved membranes that are readily permeable to NPs or NP agglomerates, which likely are formed within biological fluids or inside the cells. Parameters for potential modification include pore size, distribution and density as well as membrane thickness and composition. The pore size should be as large as possible to allow the fast passage of NPs or small agglomerates but small enough to prevent unwanted cell migration through the pores. A homogenous pore distribution and high pore density is also expected to improve NP transfer across microporous membranes. Reducing the membrane thickness is likely to improve NP crossing due to considerably lower diffusion times and reduced particle attachment to the channel walls, which in turn can lead to clogging of the membrane pores preventing further NP transport. However, the thickness of the membrane is directly linked to the mechanical properties of the membrane. As the membrane has to act as a support for the attachment and 
growth of cells, membranes for in vitro experiments have to comprise certain stability under the load of cells and liquid as well as during experimental handling. A first attempt to achieve improved membranes was the development of $500 \mathrm{~nm}$ thick silicon-nitride supports with ordered arrangements of pores that should allow easy and rapid NP transport [88]. The final challenge will be to identify materials with optimal surface properties that support the attachment and growth of cells, while simultaneously preventing the adhesion of nanomaterials. To summarize, there are several possibilities for the improvement of placental translocation models (Figure 3). Nevertheless it needs to be shown which factors have the highest impact on particle translocation and which parameters are important to achieve predictive results.

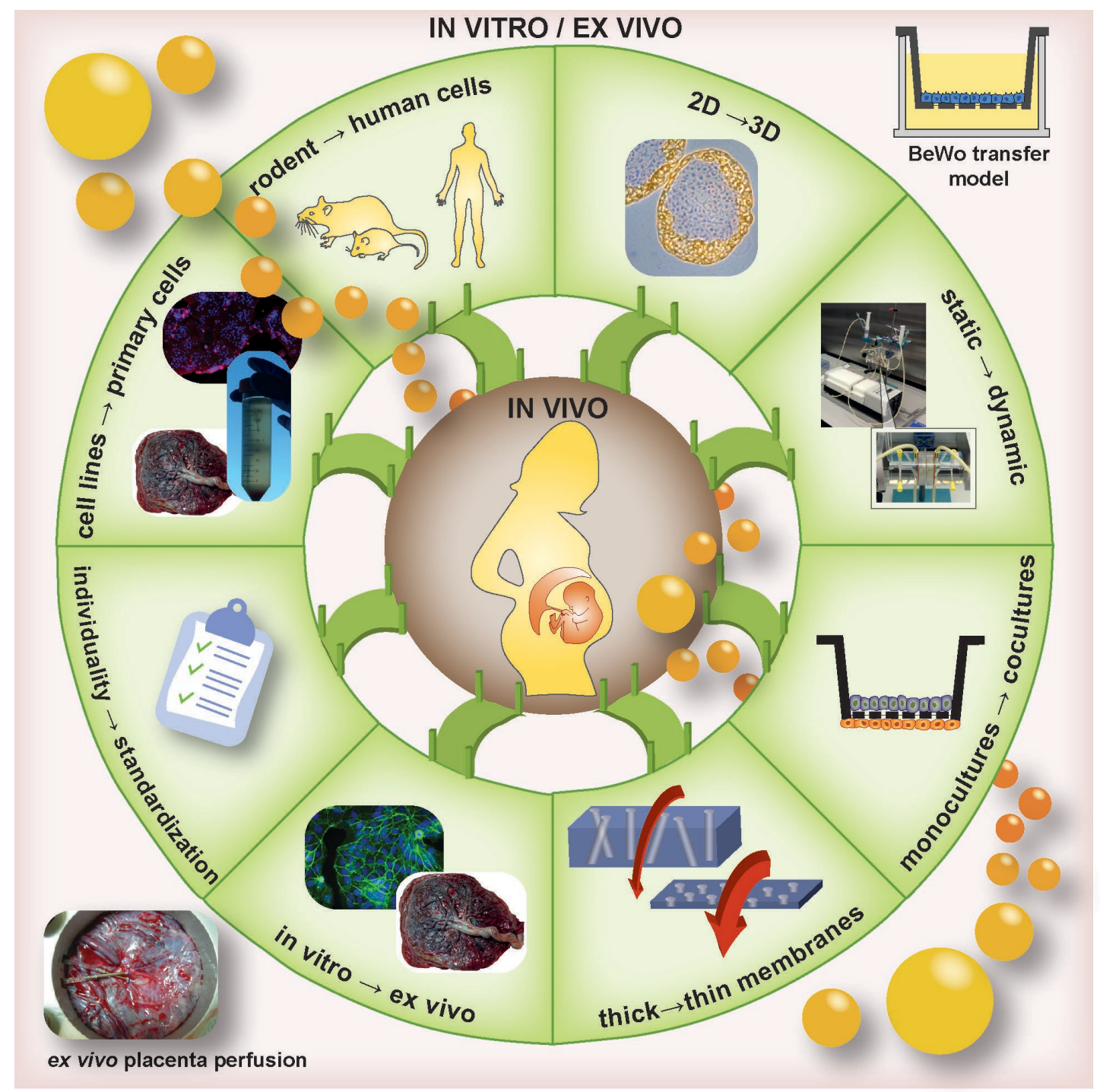

Figure 3: Strategies for the development of advanced placental models for more predictive NP transfer studies. To bridge the gap between in vitro/ex vivo transfer models and the pregnant women, improved models should be developed considering some of the following modifications: from cell lines to primary cells, from rodent to human cells, from 2D to 3D cultures, from static to dynamic cultures, from individual to standardized models and procedures, from in vitro to ex vivo models, from thick to thin membranes and from monocultures to co-cultures. 


\section{Conclusions and future perspective}

Studying translocation of NPs across the placental barrier is a relatively new research field as the initial focus was set on those biological barriers that would first get into contact with NPs such as the lung, gastrointestinal tract or the skin. With the recognition of the large potential of NPs for medical applications, internal barriers become increasingly important. A comprehensive understanding of the uptake, accumulation, translocation and effects of NPs at the human placenta is compulsory for the development of novel nanomedical therapies to treat maternal, fetal or placental disorders with reduced off-target effects. The clinical need for new approaches to deliver drugs in pregnancy is substantial [13] and therefore research on the placental transfer of NPs is a relevant and timely endeavor. In the last decade, a considerable amount of work has been performed on the translocation of various NPs at the placental barrier. It is encouraging to see that it may indeed be possible to steer NP translocation across the placental barrier by the choice of NP properties and functionalization. However, the current state of knowledge is too limited to support the design of such drug-delivery particles. To efficiently push this field of research forward, a systematic mechanism-based approach is a prerequisite and requires the development of predictive placental transfer models that are adapted to the use of NPs.

In vitro and ex vivo placental transfer models have been originally developed and used for the study of endogenous and pharmaceutical compounds. In this specific context, the models have been shown to exhibit a good predictive value for ranking the translocation of such small compounds. With the assumption that NPs will behave similar than small drugs, the models were directly applied to the study of NP transport. However, NPs have the potential to interfere with placental transfer models in unexpected ways. Therefore, a careful characterization of the NPs and the inclusion of appropriate controls will be crucial to obtain meaningful results. Furthermore, it will be essential that placental models do not only allow the ranking of placental NP transfer but also enable mechanistic studies on their uptake, accumulation, translocation and biological effects. This will require major improvements or the establishment of new in vitro placental models with high physiological relevance. For sure, the significant advances in various in vitro cell culture technologies such as microfluidics, 3D tissue cultures or $3 D$ bioprinting should be exploited, and it will be interesting to see how different parameters such as a dynamic microenvironment, co-culturing or 3D structure will influence placental transfer. Nevertheless, only those parameters should be considered that substantially advance the predictive value of the models since they should remain relatively easy to handle, highthroughput compatible and cost effective. Another major challenge will be to carefully validate these models because access to human NP transfer data is not expected in the near future and comparison to animal studies is critical considering that the placenta is the most speciesspecific organ. Yet, validation of the models will be key to get them accepted and to identify their potentials and limits. This will in turn allow devising a strategy to efficiently screen a large variety of NPs as it was already previously proposed [65]. In essence, the development and 
identification of suitable placental model(s) predictive for human pregnancy will be decisive to push the limits of our understanding of placental transport of NPs.

On a long term perspective, it will be exciting to see if advanced placental transfer models can be integrated into multi-organ chips to simulate systemic organ complexity. Combining relevant maternal organs (e.g. liver or spleen), the placental barrier and embryonic models (e.g. neurospheres or stem cell cultures) under dynamic conditions might enable the in vitro assessment of direct and indirect NP effects as well as potential teratogenic effects. Indeed such an approach might once be technically feasible as shown by the promising advances in multi-organ chip development for long term substance testing [89]. To conclude, understanding NP translocation at the placental barrier and how it can be steered is an indispensable part in the whole development of novel NP-based drug delivery systems to specifically treat the mother, fetus or placental disorders. If efficient drug loading, targeting, release as well as particle safety can be ensured, the vision of new particle-based therapies in pregnancy may eventually become reality.

\section{Executive summary}

Influence of NP characteristics on placental transfer- Is there a trend?

- NP size is a key characteristic that may allow controlling translocation across the placental barrier with higher transport for smaller particles.

- The threshold size for maternal to fetal transfer is dependent on the material type.

- Surface charge and shape are additional promising NP properties for steering placental transport that deserve increased attention.

\section{Future research on placental NP transfer - What are the urgent needs?}

- To more clearly understand how NP translocation is dependent on physical-chemical properties and functionalization, systematic studies using NP libraries, ideally varying in only one individual characteristic, are essential.

- Other relevant research topics related to NP transport are the identification of underlying transport mechanisms, the role of the protein corona and the impact of different stages of pregnancy.

\section{Current placental transfer models - Are they applicable to NP- transfer studies?}

- First pre-validation studies were performed comparing in vitro to ex vivo perfusion models but it is too early to draw conclusions on the predictive value of these models for NP transfer studies.

- There is increasing evidence that the current in vitro transfer models have limitations such as the lack of fluid flow resulting in unrealistic NP dosing or inadequate membranes that constitute a major barrier to the free transfer of NPs.

Next generation placental transfer models - Plenty of room for improvements? 
- The ex vivo perfusion model is currently used with many small modifications and would benefit from the implementation of more standardized perfusion setups and protocols.

- Advanced in vitro transfer models with higher predictability are expected from the inclusion of a dynamic microenvironment, primary cells, co-cultures and optimization of the supporting membrane.

\section{Acknowledgements}

The authors thank Dr. Marcus Koch, Head of Physical Analysis at the INM - Leibniz-Institute for New Materials $\mathrm{gGmbH}$, Saarbruecken, Germany for the provision of SEM images of microporous membranes.

\section{Financial \& competing interest disclosure}

This research is supported by funding from the BMBF-project NanoUmwelt (03X0150) and the $7^{\text {th }}$ Framework Program of the European Commission (FP7-NANOSOLUTIONS, grant agreement $n^{\circ} 309329$ and Graphene Flagship, grant agreement $n^{\circ} 604391$ ).

\section{References}

1. Evseenko D, Paxton JW, Keelan JA. Active transport across the human placenta: impact on drug efficacy and toxicity. Expert Opinion on Drug Metabolism \& Toxicology 2(1), 51-69 (2006).

2. Ganapathy V, Prasad PD, Ganapathy ME, Leibach FH. Placental transporters relevant to drug distribution across the maternal-fetal interface. Journal of Pharmacology and Experimental Therapeutics 294(2), 413-420 (2000).

3. Prouillac $\mathrm{C}$, Lecoeur $\mathrm{S}$. The role of the placenta in fetal exposure to xenobiotics: importance of membrane transporters and human models for transfer studies. Drug Metab Dispos 38(10), 1623-1635 (2010).

4. Vargesson N. Thalidomide-induced teratogenesis: History and mechanisms. Birth Defects Research Part C-Embryo Today-Reviews 105(2), 140-156 (2015).

5. Braakhuis HM, Kloet SK, Kezic $S$ et al. Progress and future of in vitro models to study translocation of nanoparticles. Archives of toxicology 89(9), 1469-1495 (2015).

*This review provides a detailed and critical overview on currently available in vitro models of the human lung, skin, intestinal and placental barrier, and highlights the need to validate these models.

6. Buerki-Thurnherr T, Von Mandach U, Wick P. Knocking at the door of the unborn child: engineered nanoparticles at the human placental barrier. Swiss Med Wkly 142 w13559 (2012).

7. Hougaard KS, Campagnolo L, Chavatte-Palmer $\mathrm{P}$ et al. A perspective on the developmental toxicity of inhaled nanoparticles. Reprod Toxicol 56 118-140 (2015).

8. Campagnolo L, Massimiani M, Palmieri G et al. Biodistribution and toxicity of pegylated single wall carbon nanotubes in pregnant mice. Part Fibre Toxicol 1021 (2013).

9. Pietroiusti A, Massimiani M, Fenoglio I et al. Low doses of pristine and oxidized single-wall carbon nanotubes affect mammalian embryonic development. ACS Nano 5(6), 4624-4633 (2011).

10. Weissig V, Guzman-Villanueva D. Nanopharmaceuticals (part 2): products in the pipeline. International Journal of Nanomedicine 10 (2015).

11. Weissig V, Pettinger TK, Murdock N. Nanopharmaceuticals (part I): products on the market. International Journal of Nanomedicine 9 4357-4373 (2014). 


\section{* Extensive 2-part review on nanoparmaceuticals currently on the market or in}

clinical trials.

12. Juliano RL. The future of nanomedicine: Promises and limitations. Science and Public Policy 39(1), 99-104 (2012).

13. Keelan JA, Leong JW, Ho D, lyer KS. Therapeutic and safety considerations of nanoparticle-mediated drug delivery in pregnancy. Nanomedicine (Lond) 10(14), 2229-2247 (2015).

** Comprehensive review on the advantages and the potential use of nanomedical approaches including some examples of hypothetical NP-drug combinations for the treatment of maternal, placental or fetal diseases.

14. Daw JR, Hanley GE, Greyson DL, Morgan SG. Prescription drug use during pregnancy in developed countries: a systematic review. Pharmacoepidemiol Drug Saf 20(9), 895-902 (2011).

* Important review showing the widespread prescription drug use during pregnancy, including medicines recognized as having potential teratogenic risks.

15. Thomas SHL, Yates LM. Prescribing without evidence - pregnancy. British Journal of Clinical Pharmacology 74(4), 691-697 (2012).

16. Ali H, Kalashnikova I, White MA, Sherman M, Rytting E. Preparation, characterization, and transport of dexamethasone-loaded polymeric nanoparticles across a human placental in vitro model. Int J Pharm 454(1), 149-157 (2013).

17. Semmler-Behnke M, Lipka J, Wenk A et al. Size dependent translocation and fetal accumulation of gold nanoparticles from maternal blood in the rat. Particle and Fibre Toxicology 11 (2014).

18. Refuerzo JS, Godin B, Bishop K et al. Size of the nanovectors determines the transplacental passage in pregnancy: study in rats. Am J Obstet Gynecol 204(6), 546 e545-549 (2011).

19. Wick $P$, Malek $A$, Manser $P$ et al. Barrier capacity of human placenta for nanosized materials. Environ Health Perspect 118(3), 432-436 (2010).

20. Cartwright L, Poulsen MS, Nielsen $\mathrm{HM}$ et al. In vitro placental model optimization for nanoparticle transport studies. Int J Nanomedicine 7 497-510 (2012).

21. Huang JP, Hsieh PC, Chen CY et al. Nanoparticles can cross mouse placenta and induce trophoblast apoptosis. Placenta doi:10.1016/j.placenta.2015.10.007 (2015).

22. Yamashita K, Yoshioka Y, Higashisaka K et al. Silica and titanium dioxide nanoparticles cause pregnancy complications in mice. Nat Nanotechnol 6(5), 321328 (2011).

23. Carreira SC, Walker L, Paul K, Saunders M. The toxicity, transport and uptake of nanoparticles in the in vitro BeWo b30 placental cell barrier model used within NanoTEST. Nanotoxicology 9 66-78 (2015).

24. Poulsen MS, Mose T, Maroun LL, Mathiesen L, Knudsen LE, Rytting E. Kinetics of silica nanoparticles in the human placenta. Nanotoxicology 9 79-86 (2015).

** This is the first study that compares the translocation of the same NPs in the ex vivo placenta perfusion model and the BeWo b30 Transwell system in order to identify the predictive value of of this in vitro placenta model.

25. Chu M, Wu Q, Yang $\mathrm{H}$ et al. Transfer of quantum dots from pregnant mice to pups across the placental barrier. Small 6(5), 670-678 (2010).

26. Lee S, Bi X, Reed RB, Ranville JF, Herckes P, Westerhoff P. Nanoparticle Size Detection Limits by Single Particle ICP-MS for 40 Elements. Environmental Science \& Technology 48(17), 10291-10300 (2014).

27. Mitrano D, Renville J, Neubauer K, Thomas R. Field-Flow Fractionation Coupled with ICP-MS for the Analysis of Engineered Nanoparticles in Environmental Samples. LC Gc Europe 25(12), 652-+ (2012).

* This study exemplarily stands for the efforts to improve nanoparticle detection in different matrices, to lower detection limits and to enable the distinction between ionic and particulate materials. 
28. Menjoge AR, Rinderknecht AL, Navath RS et al. Transfer of PAMAM dendrimers across human placenta: prospects of its use as drug carrier during pregnancy. $J$ Control Release 150(3), 326-338 (2011).

29. Sumner SC, Fennell TR, Snyder RW, Taylor GF, Lewin AH. Distribution of carbon-14 labeled $C 60$ ([14C]C60) in the pregnant and in the lactating dam and the effect of C60 exposure on the biochemical profile of urine. J Appl Toxicol 30(4), 354-360 (2010).

30. Takeda K, Suzuki K, Ishihara A et al. Nanoparticles tranferred from pregnant mice to their offspring can damage the genital and cranial nerve systems. $J$ Health Sci 55 95102 (2009).

31. Girardi G, Fraser J, Lennen R, Vontell R, Jansen M, Hutchison G. Imaging of activated complement using ultrasmall superparamagnetic iron oxide particles (USPIO) - conjugated vectors: an in vivo in utero non-invasive method to predict placental insufficiency and abnormal fetal brain development. Molecular Psychiatry 20(8), 1017-1026 (2015).

32. Austin CA, Umbreit TH, Brown KM et al. Distribution of silver nanoparticles in pregnant mice and developing embryos. Nanotoxicology 6 912-922 (2012).

33. Huang XL, Zhang $F$, Sun $X L$ et al. The genotype-dependent influence of functionalized multiwalled carbon nanotubes on fetal development. Biomaterials 35(2), 856-865 (2014).

34. Qi W, Bi JJ, Zhang XY et al. Damaging Effects of Multi-walled Carbon Nanotubes on Pregnant Mice with Different Pregnancy Times. Scientific Reports 4 (2014).

35. Choi HS, Ashitate $\mathrm{Y}$, Lee JH et al. Rapid translocation of nanoparticles from the lung airspaces to the body. Nature Biotechnology 28(12), 1300-U1113 (2010).

36. Grafmueller $S$, Manser $P$, Diener $L$ et al. Bidirectional Transfer Study of Polystyrene Nanoparticles across the Placental Barrier in an Human Placental Perfusion Model. Environ Health Perspect doi:10.1289/ehp.1409271 (2015).

37. Di Bona KR, Xu YL, Ramirez PA et al. Surface charge and dosage dependent potential developmental toxicity and biodistribution of iron oxide nanoparticles in pregnant CD-1 mice. Reproductive Toxicology 50 36-42 (2014).

38. Yang H, Sun CJ, Fan ZL et al. Effects of gestational age and surface modification on materno-fetal transfer of nanoparticles in murine pregnancy. Scientific Reports 2 (2012).

39. Kloet SK, Walczak AP, Louisse J et al. Translocation of positively and negatively charged polystyrene nanoparticles in an in vitro placental model. Toxicology in Vitro 29(7), 1701-1710 (2015).

40. Chithrani BD, Ghazani AA, Chan WCW. Determining the size and shape dependence of gold nanoparticle uptake into mammalian cells. Nano Letters 6(4), 662-668 (2006).

41. Niikura K, Matsunaga T, Suzuki T et al. Gold Nanoparticles as a Vaccine Platform: Influence of Size and Shape on Immunological Responses in Vitro and in Vivo. Acs Nano 7(5), 3926-3938 (2013).

42. Herd H, Daum N, Jones AT, Huwer H, Ghandehari H, Lehr CM. Nanoparticle geometry and surface orientation influence mode of cellular uptake. ACS Nano 7(3), 1961-1973 (2013).

43. Bitounis D, Ali-Boucetta H, Hong BH, Min DH, Kostarelos K. Prospects and Challenges of Graphene in Biomedical Applications. Advanced Materials 25(16), 2258-2268 (2013).

44. Kostarelos K, Novoselov KS. Exploring the Interface of Graphene and Biology. Science 344(6181), 261-263 (2014).

45. Wick P, Louw-Gaume AE, Kucki $\mathrm{M}$ et al. Classification framework for graphenebased materials. Angew Chem Int Ed Engl 53(30), 7714-7718 (2014).

46. Philbrook NA, Walker VK, Afrooz ARMN, Saleh NB, Winn LM. Investigating the effects of functionalized carbon nanotubes on reproduction and development in Drosophila melanogaster and CD-1 mice. Reproductive Toxicology 32(4), 442-448 (2011). 
47. Blum JL, Xiong JQ, Hoffman C, Zelikoff JT. Cadmium Associated With Inhaled Cadmium Oxide Nanoparticles Impacts Fetal and Neonatal Development and Growth. Toxicological Sciences 126(2), 478-486 (2012).

48. Myllynen PK, Loughran MJ, Howard CV, Sormunen R, Walsh AA, Vahakangas KH. Kinetics of gold nanoparticles in the human placenta. Reprod Toxicol 26(2), 130-137 (2008).

49. Rattanapinyopituk K, Shimada A, Morita T et al. Demonstration of the Clathrin- and Caveolin-Mediated Endocytosis at the Maternal-Fetal Barrier in Mouse Placenta after Intravenous Administration of Gold Nanoparticles. Journal of Veterinary Medical Science 76(3), 377-387 (2014).

50. Hougaard KS, Jackson P, Jensen KA et al. Effects of prenatal exposure to surfacecoated nanosized titanium dioxide (UV-Titan). A study in mice. Part Fibre Toxicol 7 16 (2010).

51. Krug HF, Wick P. Nanotoxicology: An Interdisciplinary Challenge. Angewandte Chemie-International Edition 50(6), 1260-1278 (2011).

52. Roesslein M, Richter V, Wick P, Krug HF. Nanomaterials and Ceramic Nanoparticles - Use without Side-Effects? Journal of Ceramic Science and Technology 4(2), 123129 (2013).

53. Jiang Y, Huo SD, Mizuhara T et al. The Interplay of Size and Surface Functionality on the Cellular Uptake of Sub-10 nm Gold Nanoparticles. Acs Nano 9(10), 9986-9993 (2015).

54. Su G, Zhou G, Mu Q et al. Effective Surface Charge Density Determines the Electrostatic Attraction between Nanoparticles and Cells. The Journal of Physical Chemistry C 116(8), 4993-4998 (2012).

55. Fadeel B. Systems biology in nanosafety research. Nanomedicine 10(7), 1039-1041 (2015).

56. Fadeel B, Feliu N, Vogt C, Abdelmonem AM, Parak WJ. Bridge over troubled waters: understanding the synthetic and biological identities of engineered nanomaterials. Wiley Interdiscip Rev Nanomed Nanobiotechnol 5(2), 111-129 (2013).

57. Mahmoudi M, Lynch I, Ejtehadi MR, Monopoli MP, Bombelli FB, Laurent S. Proteinnanoparticle interactions: opportunities and challenges. Chem Rev 111(9), 56105637 (2011).

58. Maiolo D, Del Pino P, Metrangolo P, Parak WJ, Baldelli Bombelli F. Nanomedicine delivery: does protein corona route to the target or off road? Nanomedicine (Lond) 10(21), 3231-3247 (2015).

59. Pietroiusti A, Campagnolo L, Fadeel B. Interactions of engineered nanoparticles with organs protected by internal biological barriers. Small 9(9-10), 1557-1572 (2013).

60. Monopoli MP, Aberg C, Salvati A, Dawson KA. Biomolecular coronas provide the biological identity of nanosized materials. Nat Nanotechnol 7(12), 779-786 (2012).

61. Lundqvist M, Stigler J, Elia G, Lynch I, Cedervall T, Dawson KA. Nanoparticle size and surface properties determine the protein corona with possible implications for biological impacts. Proc Natl Acad Sci U S A 105(38), 14265-14270 (2008).

62. Juch H, Nikitina L, Debbage P, Dohr G, Gauster M. Nanomaterial interference with early human placenta: Sophisticated matter meets sophisticated tissues.

Reproductive Toxicology 41 73-79 (2013).

63. Dilworth MR, Sibley CP. Review: Transport across the placenta of mice and women. Placenta 34 Suppl S34-39 (2013).

64. Hutson JR, Garcia-Bournissen F, Davis A, Koren G. The human placental perfusion model: a systematic review and development of a model to predict in vivo transfer of therapeutic drugs. Clin Pharmacol Ther 90(1), 67-76 (2011).

65. Mathiesen L, Morck TA, Zuri G et al. Modelling of human transplacental transport as performed in Copenhagen, Denmark. Basic Clin Pharmacol Toxicol 115(1), 93-100 (2014). 
66. Myllynen P, Vahakangas K. Placental transfer and metabolism: An overview of the experimental models utilizing human placental tissue. Toxicology in Vitro 27(1), 507512 (2013).

67. Ala-Kokko TI, Myllynen P, Vähäkangas K. Ex vivo perfusion of the human placental cotyledon: implications for anesthetic pharmacology. International Journal of Obstetric Anesthesia 9(1), 26-38 (2000).

68. Enders AC, Blankenship TN. Comparative placental structure. Adv Drug Deliv Rev 38(1), 3-15 (1999).

69. Panigel M, Pascaud M, Brun JL. [Radioangiographic study of circulation in the villi and intervillous space of isolated human placental cotyledon kept viable by perfusion]. J Physiol (Paris) 59(1 Suppl), 277 (1967).

70. Grafmueller S, Manser P, Krug HF, Wick P, Von Mandach U. Determination of the Transport Rate of Xenobiotics and Nanomaterials Across the Placenta using the ex vivo Human Placental Perfusion Model. doi:doi:10.3791/50401(76), e50401 (2013).

71. Malek A, Obrist C, Wenzinger S, Von Mandach U. The impact of cocaine and heroin on the placental transfer of methadone. Reprod Biol Endocrinol 761 (2009).

72. Stark WJ. Nanoparticles in biological systems. Angew Chem Int Ed Engl 50(6), 1242 1258 (2011).

73. Bruinink A, Wang J, Wick P. Effect of particle agglomeration in nanotoxicology. Archives of toxicology 89(5), 659-675 (2015).

74. Grafmueller S, Manser P, Diener $L$ et al. Transfer studies of polystyrene nanoparticles in the ex vivo human placenta perfusion model: key sources of artifacts. Science and Technology of Advanced Materials 16(4), 044602 (2015).

75. Lee JS, Romero R, Han YM et al. Placenta-on-a-chip: a novel platform to study the biology of the human placenta. J Matern Fetal Neonatal Med doi:10.3109/14767058.2015.1038518 1-9 (2015).

76. Miura S, Sato K, Kato-Negishi M, Teshima T, Takeuchi S. Fluid shear triggers microvilli formation via mechanosensitive activation of TRPV6. Nat Commun 68871 (2015).

77. Levkovitz R, Zaretsky U, Gordon Z, Jaffa AJ, Elad D. In vitro simulation of placental transport: part I. Biological model of the placental barrier. Placenta 34(8), 699-707 (2013).

78. Li H, Van Ravenzwaay B, Rietjens IM, Louisse J. Assessment of an in vitro transport model using BeWo b30 cells to predict placental transfer of compounds. Archives of toxicology 87(9), 1661-1669 (2013).

79. Poulsen MS, Rytting E, Mose T, Knudsen LE. Modeling placental transport: correlation of in vitro BeWo cell permeability and ex vivo human placental perfusion. Toxicol In Vitro 23(7), 1380-1386 (2009).

80. Rytting E. Exploring the interactions of nanoparticles with multiple models of the maternal--fetal interface. Nanotoxicology 9 Suppl 1 137-138 (2015).

81. Dekali S, Gamez C, Kortulewski T, Blazy K, Rat P, Lacroix G. Assessment of an in vitro model of pulmonary barrier to study the translocation of nanoparticles. Toxicology Reports 1 157-171 (2014).

82. George I, Vranic S, Boland S, Courtois A, Baeza-Squiban A. Development of an in vitro model of human bronchial epithelial barrier to study nanoparticle translocation. Toxicology in Vitro 29(1), 51-58 (2015).

83. Ye D, Raghnaill MN, Bramini $\mathrm{M}$ et al. Nanoparticle accumulation and transcytosis in brain endothelial cell layers. Nanoscale 5(22), 11153-11165 (2013).

84. Brun E, Barreau F, Veronesi $\mathrm{G}$ et al. Titanium dioxide nanoparticle impact and translocation through ex vivo, in vivo and in vitro gut epithelia. Particle and Fibre Toxicology 11 (2014).

85. Mathiesen L, Mose T, Morck TJ et al. Quality assessment of a placental perfusion protocol. Reproductive Toxicology 30(1), 138-146 (2010). 
86. Walczak AP, Kramer E, Hendriksen PJ et al. Translocation of differently sized and charged polystyrene nanoparticles in in vitro intestinal cell models of increasing complexity. Nanotoxicology 9(4), 453-461 (2015).

87. Kelm JM, Fussenegger M. Microscale tissue engineering using gravity-enforced cell assembly. Trends in Biotechnology 22(4), 195-202 (2004).

88. CSEM - Centre Suisse d'Electronique et de Microtechnique, http://www.csem.ch/site/card.asp?pld=19709.

89. Maschmeyer I, Lorenz AK, Schimek $\mathrm{K}$ et al. A four-organ-chip for interconnected long-term co-culture of human intestine, liver, skin and kidney equivalents. Lab on a Chip 15(12), 2688-2699 (2015). 